\title{
Effect Carrier Based and Liquid Biofertilizers at Different Phosphorus Levels on Productivity of Hybrid Maize
}

\author{
Pragya Gautam $^{1 *}$, L.N. Dashora ${ }^{1}$, N.S. Solanki ${ }^{1}$, R.H. Meena ${ }^{2}$ and B. Upadhyay $^{3}$ \\ ${ }^{1}$ Department of Agronomy, ${ }^{2}$ Department of Agricultural Chemistry and Soil Science, Maharana \\ Pratap University of Agriculture and Technology, Udaipur (Rajasthan), India \\ ${ }^{3}$ Department of Agricultural Statistics, Rajasthan College of Agriculture, Maharana Pratap \\ University of Agriculture and Technology, Udaipur (Rajasthan), India \\ *Corresponding author
}

\section{A B S T R A C T}

Keywords

Hybrid maize,

Phosphorus, Liquid PSB, Yield attributes and yield.

Article Info

Accepted:

10 October 2017

Available Online:

10 December 2017
A field experiment was conducted to study the comparative performance of carrier based and liquid Biofertilizers at different phosphorus levels in hybrid maize during kharif, 2016 at Instructional Farm, Rajasthan College of Agriculture, Udaipur. The experiment was laid out in a factorial randomized block design with three replications consisted 15 treatments combinations of three phosphorus levels (30, 45 and $60 \mathrm{~kg} \mathrm{P}_{2} \mathrm{O}_{5} \mathrm{ha}^{-1}$ ) and five bio-fertilizers (LBF1, LBF2, CB, LBF1+CB and LBF2+CB). The results revealed that application of $\mathrm{LBF} 1+\mathrm{CB}$ at $60 \mathrm{~kg} \mathrm{P}_{2} \mathrm{O}_{5} \mathrm{ha}^{-1}$ significantly increased yield attributes viz., seed, stover and biological yields as well as harvest index.

\section{Introduction}

Maize (Zea may L.) is one of the most important crop and widely cultivated around the world in $132 \mathrm{~m}$ ha with production of 790 $\mathrm{m}$ t. FAO predicted that an additional $60 \mathrm{~m}$ tonnes of maize grain will be needed from the annual global harvest by 2030 . The demand for maize as an animal feed will continue to grow faster than the demand for its use as a human food, particularly in Asia, where a doubling of production is expected from the present level of $165 \mathrm{~m}$ tonnes to almost $400 \mathrm{~m}$ tonnes in 2030 (Paliwal et al., 2000). Maize is the third most important cereal crop that is considered as integral component of food security at global level. It is source for a large number of industrial products viz., maize corn, corn starch, corn oil, baby corn, popcorn, dairy feed, poultry feed, piggery, agro industries, and so on. The huge potential for export has added the demand for maize all over the world. In India, it is an important crop not only in terms of acreage but also in context to their versatility for adoption under wide range of agro-climatic conditions. Currently maize is cultivated over $9.23 \mathrm{~m}$ ha area with $23.67 \mathrm{~m} \mathrm{t}$ production with average yield of $25.64 \mathrm{q} \mathrm{ha}^{-1}$ (Govt. of India, 2015). In Rajasthan it ranks first in respect of area, 
wherein this crop occupies $0.89 \mathrm{~m}$ ha area with an annual production of $1.55 \mathrm{~m}$ tonnes with average yield $17.40 \mathrm{q} \mathrm{ha}^{-1}$ (Govt. of Raj., 2015a).

Higher yield of maize can be obtained through the judicious use of plant nutrients. The mineral fertilizers will continue to play the key role in the augmentation of the food production in the entire world. In India recently developed single cross hybrids of maize require higher phosphorus (Choudhary, 2016). In recent past, due to escalating cost of chemical fertilizers and with objective to minimizing environmental pollution, the search of alternative source of plant nutrients is imperative.

The integrated plant nutrient supply envisages conjunctive use of inorganic and organic sources of plant nutrients and use of biofertilizers for crop productivity besides sustaining soil health. In the recent years, microbial fertilizers like phosphate solubilizing bacteria (PSB) and liquid bio fertilizer have shown tremendous potential as these are eco-friendly and low cost agriculture inputs. There is a great need for research on phosphorus solubilization for energy conservation. Most soils of Rajasthan state are medium to low in phosphorus content. Hence, inoculation with suitable strains of PSB biofertilizers in these soils may help in boosting up production because of increasing microbial population and consequently increased solubilization of unavailable phosphorus by PSB. The mode of action of PSB involves secretion of organic acids which lower the $\mathrm{pH}$ and increase the availability of sparingly soluble phosphorus.

Interest in liquid bio-fertilizer formulations has grown rapidly all over the world, since the liquid bio-fertilizers of good quality hold great promise in agriculture because of benefits over the conventional carrier based bio-fertilizers such as longer shelf life, better survival on seed and better nodulation, cost saving on carrier material i.e. pulverization, neutralization, sterilization, contamination free and convenience of handling, storage and transportation (Hedge, 2008).

However, it is often difficult to mix uniformly peat-based inoculants with seeds. Solid-based inoculants also tend to plug precision air seeders (Singleton et al., 2002). Because of these difficulties, inoculants producers have been shifting to liquid inoculant formulations instead of solid-based inoculants.

Liquid inoculants can be prepared in both culture or as frozen concentrates, and conveniently mixed with water for spraying into seed furrow or coating directly onto the seed without using sticker. Moreover, liquid inoculants coat the seeds uniformly and dry when applied through seed auger. Seeds coated with liquid inoculants flow properly when planted by using various types of seeding equipments (Tittabutr et al., 2007; Frenandes and Diaz-Zorita, 2009). It is recognized that neither bio-fertilizers alone nor exclusive application of phosphorus through chemical fertilizers can sustain soil health as well productivity in modern farming where nutrient turn-over in soil plant system is quite high.

\section{Materials and Methods}

A field experiment was conducted at Instructional Farm, Rajasthan College of Agriculture, Udaipur during kharif season 2016. The soil of the experimental field was clay loam in texture, slightly alkaline in reaction ( $\mathrm{pH} 7.6)$, low in available nitrogen (226.7 $\mathrm{kg} \mathrm{ha}^{-1}$ ), and available phosphorus (19.4 $\mathrm{kg} \mathrm{ha}^{-1}$ ) while medium in available potassium $\left(254.6 \mathrm{~kg} \mathrm{ha}^{-1}\right)$. The experiment was laid out in factorial randomized block design and replicated thrice with three levels 
of phosphorus $(30,45,60 \mathrm{~kg}$ ha-1 and five treatments of Biofertilizer i.e. Liquid bio fertilizer-1* (LBF1), Liquid bio fertilizer-II*, (LBF2), Carrier based culture (CB). Liquid bio fertilizer-1 + Carrier based culture and Liquid bio fertilizer-1I +Carrier based culture. As per treatment whole $\mathrm{P}$ was applied at sowing through DAP adjusting the amount of nitrogen PSB bio-fertilizer was applied through seed treatment as per their recommendation. The Liquid biofertilizer1 and Liquid bio fertlizer2 contain $10^{10} \mathrm{cfu} / \mathrm{ml}$ and $10^{9} \mathrm{cfu} / \mathrm{ml}$, respectively. Uniform recommended dose of nitrogen was supplied to crop through splitting urea and adjusting the amount of nitrogen present in DAP.

\section{Results and Discussion}

\section{Effect of phosphorus}

Application of different levels of phosphorus (30, 45 and $60 \mathrm{~kg} \mathrm{P}_{2} \mathrm{O}_{5} \mathrm{ha}^{-1}$ ) significantly improved the yield and yield attributing parameters. However, it fails to create significant impact on cobs plant ${ }^{-1}$ (Table 1). The increasing levels of phosphorus application significantly increased grain weight plant ${ }^{-1}$, grain $\mathrm{cob}^{-1}$, cob girth, shelling and test weight. Highest grain weight plant $^{-1}$ $(70.19 \mathrm{~g})$, grain $\mathrm{cob}^{-1}(310.40)$, cob girth $(16.0$ $\mathrm{cm})$, shelling $(78.79 \%)$ and test weight $(203.85 \mathrm{~g})$ were recorded with application of $60 \mathrm{~kg} \mathrm{P}_{2} \mathrm{O}_{5} \mathrm{ha}^{-1}$. The cob length was also increased with increasing levels of phosphorus and highest cob length was recorded with application of $60 \mathrm{~kg} \mathrm{P}_{2} \mathrm{O}_{5} \mathrm{ha}^{-1}$ however, it was statistically at par with application of $45 \mathrm{~kg} \mathrm{P}_{2} \mathrm{O}_{5} \mathrm{ha}^{-1}$. The grain, stover and biological yields (Table 2) of hybrid maize were significantly influenced by various levels of phosphorus. The highest grain yield (3937 kg ha-1), stover yield (5849 $\mathrm{kg} \mathrm{ha}^{-1}$ ) and biological yield (9786 kg ha $\left.{ }^{-1}\right)$ were recorded with the application of $60 \mathrm{~kg}$ $\mathrm{P}_{2} \mathrm{O}_{5} \mathrm{ha}^{-1}$. The increase in grain and stover yield might be due to remarkable improvement in growth and yield attributes. Increase in grain yield per hectare in response to increasing levels of $\mathrm{P}$ is due to increased number of grains per cob and test weight. Phosphorus is particularly important for root development and good crop establishment. This indicated that $\mathrm{P}$ at the rate of $60 \mathrm{~kg} \mathrm{ha}^{-1}$ might be the optimum rate for improvement in number of grains $\mathrm{cob}^{-1}$ which ultimately had a direct effect on grain yield. Similar results were also reported by Hussain et al., (2006) who found that grain yield increased with phosphorus application and plots receiving $90 \mathrm{~kg} \mathrm{P} \mathrm{ha}{ }^{-1}$ gave maximum grain yield as compared to lower dose grain yield. A good and optimum supply of $\mathrm{P}$ is associated with increased root growth due to which the plants explore more soil nutrients and moisture. That is why the grain yield was the lowest in the control plots because lack of $\mathrm{P}$ deteriorated the roots growth of the plants which negatively affected the other physiological functions of the maize plants in the control plots. The observed relationship corroborates with findings of Abdullah (2008), Nath et al., (2009), Khazaei et al., (2010), Dhaka et al., (2014) and Snehlatha et al., (2015).

\section{Effect of biofertilizer}

Data presented in Table 1 reveal that application phosphatic Biofertilizers were influenced the yield and yield attributing characteristics of maize. The results showed that dual inoculation had significant difference in grain weight plant ${ }^{-1}$, grain $\mathrm{cob}^{-1}$, cob girth, shelling and test weight as compared single inoculation. Highest grain weight plant ${ }^{-1}(68.52 \mathrm{~g})$, grain $\mathrm{cob}^{-1}(307.33)$, cob girth $(16.52 \mathrm{~cm})$, cob length $(22.95 \mathrm{~cm})$, shelling $(79.27 \%)$ and test weight (202.59 g) with the inoculation with liquid and carrier based Biofertilizer (LBF1+CB). 
Table.1 Effect of phosphorus levels and bio-fertilizers on yield attributing characters of maize

\begin{tabular}{|c|c|c|c|c|c|c|c|}
\hline Treatments & $\begin{array}{c}\text { Cobs } \\
\text { plant }^{-1}\end{array}$ & $\begin{array}{c}\text { Grain weight } \\
\text { plant }^{-1}(\mathrm{~g})\end{array}$ & $\begin{array}{c}\text { Grains } \\
\text { cob }^{-1}\end{array}$ & $\begin{array}{c}\text { Cob girth } \\
(\mathrm{cm})\end{array}$ & $\begin{array}{c}\text { Cob length } \\
(\mathrm{cm})\end{array}$ & $\begin{array}{c}\text { Test } \\
\text { weight }(\mathrm{g}) \\
\end{array}$ & $\begin{array}{c}\text { Shelling } \\
(\%)\end{array}$ \\
\hline \multicolumn{8}{|c|}{ Phosphorus levels $\left(\mathrm{P}_{2} \mathrm{O}_{5} \mathrm{~kg} \mathrm{ha}^{-1}\right)$} \\
\hline 30 & 1.15 & 53.19 & 267.07 & 13.99 & 18.43 & 185.20 & 70.41 \\
\hline 45 & 1.16 & 63.56 & 296.27 & 14.67 & 19.37 & 195.23 & 74.25 \\
\hline 60 & 1.16 & 70.19 & 310.40 & 16.00 & 20.61 & 203.85 & 78.79 \\
\hline SEm \pm & 0.015 & 1.278 & 4.874 & 0.302 & 0.334 & 2.466 & 1.343 \\
\hline $\mathrm{CD}(\mathrm{P}=0.05)$ & NS & 3.701 & 14.119 & 0.875 & 0.967 & 7.142 & 3.891 \\
\hline \multicolumn{8}{|l|}{ Bio-fertilizers } \\
\hline LBF1 & 1.16 & 60.24 & 280.67 & 14.31 & 19.72 & 192.03 & 72.72 \\
\hline LBF2 & 1.16 & 59.52 & 278.33 & 14.11 & 17.86 & 189.07 & 70.98 \\
\hline $\mathrm{CB}$ & 1.16 & 57.74 & 284.11 & 13.87 & 17.50 & 190.39 & 73.18 \\
\hline $\mathrm{LBF} 1+\mathrm{CB}$ & 1.16 & 68.52 & 307.33 & 16.52 & 22.95 & 202.59 & 79.27 \\
\hline $\mathrm{LBF} 2+\mathrm{CB}$ & 1.16 & 65.54 & 305.78 & 15.61 & 20.97 & 199.73 & 76.18 \\
\hline SEm \pm & 0.020 & 1.64 & 6.29 & 0.39 & 0.43 & 3.18 & 1.73 \\
\hline $\mathrm{CD}(\mathrm{P}=0.05)$ & NS & 4.77 & 18.22 & 1.12 & 1.04 & 9.22 & 5.02 \\
\hline
\end{tabular}

Table.2 Effect of phosphorus levels and bio-fertilizers on grain, stover, biological yields and harvest index of maize

\begin{tabular}{|c|c|c|c|c|}
\hline \multirow[t]{2}{*}{ Treatments } & \multicolumn{3}{|c|}{ Yield $\left(\mathrm{kg} \mathrm{ha}^{-1}\right)$} & \multirow[t]{2}{*}{ HI $(\%)$} \\
\hline & Grain & Stover & Biological & \\
\hline \multicolumn{5}{|c|}{ Phosphorus levels $\left(\mathrm{P}_{2} \mathrm{O}_{5} \mathrm{~kg} \mathrm{ha}^{-1}\right)$} \\
\hline 30 & 3130 & 4652 & 7782 & 4022 \\
\hline 45 & 3647 & 5421 & 9068 & 4029 \\
\hline 60 & 3937 & 5849 & 9786 & 4025 \\
\hline SEm \pm & 91 & 142 & 202 & 635 \\
\hline $\mathrm{CD}(\mathrm{P}=0.05)$ & 264 & 413 & 587 & NS \\
\hline \multicolumn{5}{|l|}{ Bio-fertilizers } \\
\hline LBF1 & 3458 & 5124 & 8582 & 4035 \\
\hline LBF2 & 3377 & 5072 & 8449 & 3990 \\
\hline $\mathrm{CB}$ & 3510 & 5047 & 8557 & 4107 \\
\hline $\mathrm{LBF} 1+\mathrm{CB}$ & 3876 & 5747 & 9623 & 4035 \\
\hline $\mathrm{LBF} 2+\mathrm{CB}$ & 3637 & 5547 & 9184 & 3960 \\
\hline SEm \pm & 117 & 184.5 & 261 & 819 \\
\hline $\mathrm{CD}(\mathrm{P}=0.05)$ & 341 & 534 & 758 & NS \\
\hline
\end{tabular}


This may be attributing to phosphorus biofertilizer which induced the uptake ability of the roots to nutrients and positive increase in the yield parameters because of improving the root system as a source-sink relationship to the reproductive part (shoot), that agree with Mohammed et al., 2001 and Ozturk et al., 2003. Further results showed that inoculation with LBF1 + CB significantly increased grain yield (3875 $\left.\mathrm{kg} \mathrm{ha}^{-1}\right)$ by 12.0 , 17.8 and 10.4 per cent over LBF1, LBF2 and CB (3458, 3377 and $3510 \mathrm{~kg} \mathrm{ha}{ }^{-1}$, respectively). However, it was noticed that LBF1+CB (3876 kg ha ${ }^{-1}$ ) and LBF2+CB (3637 $\mathrm{kg} \mathrm{ha}^{-1}$ ) were statically at par. A positive effect of $\mathrm{LBF} 1+\mathrm{CB}$ on grain and straw yields might be due to more population of phosphate solubilizing bacteria, better survival of inoculated microorganisms in the rhizosphere and seed surface due to presence of cell protectant chemicals such as PVP and trehalose in it. Application of liquid based biofertilizer as well as carrier based biofertilizer enhanced high number of cells in the rhizosphere, multiplication and subsistence of cells due to availability of carbon and energy sources. This could be due to application of more population of PSB though seed treatment, which gave competitive advantage and allowed better survival of the inoculated microorganisms in rhizosphere.

It is concluded that maize plants fertilized with $60 \mathrm{~kg} \mathrm{P}_{2} \mathrm{O}_{5} \mathrm{ha}^{-1}$ and inoculated with LBF1+CB improved yield attributing characteristics viz. grain weight plant $^{-1}$, grain $\mathrm{cob}^{-1}$, cob girth, shelling and test weight and grain, stover and biological yields. So phosphorus application at $60 \mathrm{~kg} \mathrm{P}_{2} \mathrm{O}_{5} \mathrm{ha}^{-1}$ and inoculated with $\mathrm{LBF} 1+\mathrm{CB}$ appeared the best treatment for hybrid maize.

\section{References}

Abdullah, 2008. Effect of nitrogen on fresh ear yield and kernel protein content of sweet corn (Zea mays L. Ssp. saccharata) under upper Mesopotamia region of Turkey. Indian Journal of Agricultural Sciences78(1):50-52.

Dhaka, S. K., Singh, D., Nepalia, V., Sulochana and Dhewa, J. 2014. Performance of Sweet Corn (Zea mays. L. ssp. saccharata) varieties at varying fertility levels. Forage Research 40(3): 195-198.

Govt. of India, 2015. Directorate of economics and statistics, Department of Agriculture and cooperation, Ministry of Agriculture, Government of India.

Govt. of Raj. 2015a. Vital Agriculture Statistics, Statistical Cell, Directorate of Agriculture, Pant KrishiBhawan, Jaipur, pp. 47.

Hussain, N., A.Z. Khan, H. Akbar and S. Akhtar. 2006. Growth factors and yield of maize as influenced by phosphorus and potash fertilization. Sarhad J. Agric. 22(4): 579-583.

Khazaei, E., Alikhani, M. A., Yari, L. and Khadan, A. 2010. Study the correlation, regression and path coefficient analysis in sweet corn (Zea mays v. saccharata) under different levels of plant density and nitrogen rate. ARPN Journal of Agricultural and Biological Science 5(6): 14-20.

Manea, M., Sen, A., Kumar, A., Kumar, P., Singh, Y., Srivastava, V. N., and Singh, R. K. 2015. Performance of baby corn (Zea mays L.) under different fertility and planting methods and its residual effect on sorghum. Indian Journal of Agronomy, 60(1): 45-51.

Mohammed, A.S., M.A. AbdelMonem, H. E. Khalifa, M. Beider, I.A. El Ghandour, Y.G.M.Galal. 2001. Using biofertilizers for maize production: response and economic return under different irrigation treatments. J. Sustain. Agricultur, (19). 41-48.

Nath, K., Nepalia, V. and Singh, D. 
2009.Effect of integrated nutrient management on growth and yield of sweet corn (Zea mays Ssp. saccharata). Annals of Agricultural Research New Series, 73-76.

Noor, A. 2003. The effect of rock phosphate and combination of phosphatesolubilizing Bacteria and farm yard manure on soil available $\mathrm{P}$ and growth of soybean on Ultisols. Bul. Agron. 31:100-106.

Paliwal, R. L., Granados, G., Lafitte, H. R., Violic, A. D. and Marathee, J. P. 2000.Tropical Maize. In: Improvement and Production, Food and Agriculture Organization of the Unites Nations, Rome, Italy.

Snehlata. 2015. Performance of Quality Protein Maize (Zea mays L.) Varieties at Varying Fertility Levels. M.Sc. Thesis, Department of Agronomy, MPUAT, Udaipur.

Sobhana, V., Kumar, A., Idnani, L.K., Singh, I. and Shivdhar. 2011. Plant population and nutrient requirement for baby corn hybrids (Zea mays L.). Indian Journal of Agronomy57 (3):45-51.

\section{How to cite this article:}

Pragya Gautam, L.N. Dashora, N.S. Solanki, R.H. Meena and Upadhyay, B. 2017. Effect Carrier Based and Liquid Biofertilizers at Different Phosphorus Levels on Productivity of Hybrid Maize. Int.J.Curr.Microbiol.App.Sci. 6(12): 922-927. doi: https://doi.org/10.20546/ijcmas.2017.612.100 